\title{
(ivin \\ Peningkatan Hasil Belajar IPS Materi SDA dan Pemanfaatannya melalui Model Pembelajaran Inquiry Berbantuan Media Games Book di Kelas IV Sekolah Dasar
}

\author{
Acep Saepul Rahmat ${ }^{1}$, M. Syarif Sumantri ${ }^{2,}$, Deasyanti $^{3}$ \\ ${ }^{1}$ Program Pascasarjana Universitas Negeri Jakarta, Jl. Rawamangunmuka ,Jakarta Timur \\ ${ }^{2}$ Program Pascasarjana Universitas Negeri Jakarta, Jl. Rawamangunmuka ,Jakarta Timur \\ ${ }^{3}$ Program Pascasarjana Universitas Negeri Jakarta, Jl. Rawamangunmuka ,Jakarta Timur \\ *Corresponding author: acepsaepulrahmat@yahoo.com; mohamadsumantri@gmail.com; deasy.edupsy@yahoo.com
}

Diterima 6 Mei 2018; Direview 9 Mei 2018; Diterima 17 Mei 2018

Diterbitkan online 4 Juni 2018

\begin{abstract}
Abstrak
Penelitian ini bertujuan untuk meningkatkan hasil belajar IPS meliputi tes hasil belajar dan keterampilan sosial melalui model pembelajaran Inquiry berbantuan media Games Book pada siswa kelas IV SD Negeri Karamatjaya Kecamatan Cigalontang Kabupaten Tasikmalaya. Penelitian ini merupakan penelitian tindakan kelas dengan menggunakan model Kemmis dan Mc Taggart. Penelitian tindakan ini diakhiri dalam dua siklus. Hal ini didasarkan berdasar hasil penelitian pada siklus ke II mengalami peningkatan yang sangat signifikan, disertai dengan telah tercapainya kriteria keberhasilan tindakan. Setiap siklus terdiri dari tahapan perencanaan, tindakan, observasi dan refleksi. Data dikumpulkan melalui tes hasil belajar, lembar observasi pengamatan perilaku dan dokumentasi. Hasil analisis data diperoleh bahwa aktivitas guru dan siswa meningkat setiap siklus. Rata-rata tes hasil belajar IPS pada pra tindakan dengan nilai 70,45, siklus I dengan nilai 74.45 dan siklus II dengan nilai rata-rata 88 . Persentase ketuntasan dari pra tindakan sebesar 30\% meningkat pada siklus II menjadi 100\% tuntas dengan persentase peningkatan sebesar 70\%. Rata-rata hasil observasi pengamatan perilaku keterampilan sosial pada siklus II menunjukan terdapat peningkatan dan perubahan dari siklus I pertemuan pertama dengan skor 8 atau 26,66\%, siklus I pertemuan kedua dengan skor 11 atau 36,66\%, siklus II pertemuan pertama 17 atau 56,66\%, dan siklus II pertemuan kedua dengan skor rata-rata 25 atau 83,33\%. Persentase ketuntasan dari pra tindakan 0 atau $0 \%$ menjadi 18 orang yang tuntas atau 90\% tuntas pada siklus II pertemuan kedua dengan persentase peningkatan sebesar 90\%. Hasil penelitian membuktikan bahwa model pembelajaran Inquiry dapat meningkatkan hasil belajar IPS materi Sumber Daya Alam dan Pemanfaatannya pada siswa kelas IV SD Negeri Karamatjaya Tasikmalaya.
\end{abstract}

Kata Kunci: Hasil Belajar, Ilmu Pengetahuan Sosial, Model Pembelajaran, Inquiry, Media, Games Book, Penelitian Tindakan.

\section{PENDAHULUAN}

Proses pendidikan yang dilaksanakan di sekolah mengharapkan siswa dapat mengembangkan potensi terbaiknya sesuai dengan tujuan pembelajaran. Guru sebagai pengajar bukan hanya sekedar menyampaikan informasi terkait dengan materi pembelajaran, akan tetapi harus mampu menciptakan suasana kelas yang menyenangkan supaya siswa terlibat aktif dalam proses pembelajaran serta siswa dapat mengembangkan seluruh kemampuan yang ada pada dalam dirinya. Hal ini sejalan dengan UU No. 20 tahun 2003 tentang sistem pendidikan nasional, bahwa pendidikan adalah usaha sadar dan terencana untuk mewujudkan suasana belajar dan proses pembelajaran agar peserta didik secara aktif mengembangkan potensi dirinya untuk memiliki kekuatan spiritual keagamaan, 
pengendalian diri, kepribadian, kecerdasan, akhlak mulia, serta keterampilan yang diperlukan dirinya, masyarakat, bangsa dan negara.

Di setiap jenjang pendidikan khususnya di Sekolah Dasar, peserta didik diharuskan menempuh sejumlah mata pelajaran tertentu, diantaranya adalah mata pelajaran Ilmu Pengetahuan Sosial.

Dalam Peraturan Permendikbud No. 24 Tahun 2006 dijelaskan bahwasannya

"Ilmu Pengetahuan Sosial (IPS) merupakan salah satu mata pelajaran yang diberikan mulai dari SD/MI/SDLB sampai SMP/MTs/SMPLB. IPS mengkaji seperangkat peristiwa, fakta, konsep, dan generalisasi yang berkaitan dengan isu sosial. Pada jenjang SD/MI mata pelajaran IPS memuat materi Geografi, Sejarah, Sosiologi, dan Ekonomi. Melalui mata pelajaran IPS, peserta didik diarahkan untuk dapat menjadi warga negara Indonesia yang demokratis, dan bertanggung jawab, serta warga dunia yang cinta damai”.

Pada jenjang SD/MI mata pelajaran IPS memuat substansi materi meliputi pemahaman lingkungan, kejadian sosial, interaksi sosial, perekonomian serta kondisi ruang dan daerah. IPS mempunyai misi yang sangat esensial dan strategis yakni membentuk, mengembangkan, dan melatih siswa menjadi warga masyarakat, bangsa, dan negara yang mempunyai pengetahuan, pemahaman, dan keterampilan yang komprehensif sosial, sehingga mampu menjalani kehidupan masyarakat modern dan tataran kehidupan masyarakat global. Selain itu pula melalui mata pelajaran IPS diharapkan siswa diarahkan untuk menjadi seseorang yang mampu memiliki jiwa sosial yang tinggi, memiliki kemandirian, kreatif dan demokratis. Jarolimek mengemukakan bahwa pada dasarnya pendidikan IPS berhubungan erat dengan pengetahuan, keterampilan sosial, sikap, dan nilai-nilai yang memungkinkan siswa berperan serta dalam kelompok masyarakat di mana ia tinggal.

Sejalan dengan hal tersebut, Hosnan (2014,hlm.356) menjelaskan beberapa tuntutan pembelajaran abad 21 adalah mengarah pada 4C yang memuat Communication, Collaboration, Critical Thinking and Problem Solving dan Creativity and Innovation.

Siswa Sekolah Dasar memiliki karakteristik pemahaman yang bersifat operasional konkrit. Sesuai dengan apa yang dikemukakan oleh Piaget (dalam Susanto, 2013,hlm.77). "Pada usia 7-11 Tahun siswa sudah mulai memahami aspek-aspek komulatif materi, memahami cara mengkombinasikan beberapa golongan benda yang bervariasi tingkatannya, serta berfikir sistematis mengenai benda-benda dan peristiwa -peristiwa yang konkrit".

Salah satu yang dapat dikembangkan untuk mencapai hal tersebut adalah dengan mengoptimalkan proses pembelajaran melalui penggunaan model pembelajaran interaktif dan komunikatif. Artinya desain pembelajaran yang mengaktifkan siswa dalam proses 
pembelajaran.

Model pembelajaran merupakan salah satu cara untuk mengatasi berbagai problematika dalam pelaksanaan pembelajaran.

Model pembelajaran inquiry banyak dikembangkan oleh para tokoh pakar pendidikan diantaranya adalah Suchman (1962). Suchman meyakini bahwasannya anak-anak merupakan individu yang penuh rasa ingin tahu akan segala sesuatu. (Ratni Sirait, 2012,hlm.254).

Hanafiah, 2009 dalam (Siti Masitoh, 2016,hlm.336) damengemukakan bahwa Inquiry merupakan rangkaian kegiatan pembelajaran yang melibatkan seluruh kemampuan siswa secara optimal untuk mencari dan menyelidiki secara sistematis, kritis dan logis sehingga dapat menemukan sendiri pengetahuan, sikap serta keterampilan siswa.

Keselman, 2003 dalam (Margus Pedaste,2015:154) menyatakan bahwa Inquiry-based learning is an educational strategy in which students follow methods and practices similar to those of professional scientists in order to construct knowledge.

Carol C Kuhthau (2007,hlm.2) mempertegas bahwa

Inquiry is an ap proach to learning whereby students find and use a variety of sources of infor ma tion and ideas to in crease their understand ing of a problem, topic, or is sue. It requires more of them than sim ply an swer ing ques tions or get ting a right an swer. It es pouses in ves tigation, exploration, search, quest, research, pursuit, and study.
Berdasar pernyataan tersebut, inquiry merupakan model pembelajaran yang menekankan pada proses, dimana siswa menemukan dan menggunakan berbagai sumber informasi dan gagasan untuk mendapatkan pemahaman mereka tentang masalah, topik, atau konsep materi pembelajaran melalui penyelidikan, eksplorasi, pencarian, pencarian, penelitian, dan telaah sumber materi pembelajaran.

Menurut Brunner (Hosnan, 2014,hlm.346) mengenalkan bahwa model Inquiry mengarah pada pentingnya siswa untuk belajar menemukan, memecahkan masalah sehingga siswa mampu menemukan konsep secara mandiri.

Diantara beberapa model pembelajaran inquiry yang ada, model pembelajaran guide inquiry (terbimbing) merupakan salah satu jenis model pembelajaran yang relevan diterapkan di Sekolah Dasar. Terlebih karena alasan siswa sekolah dasar masih membutuhkan arahan dan bimbingan dari guru.

Hudoyono (Markaban,2006,hlm.154) mempertegas bahwa

"Dalam usaha menemukan suatu konsep siswa memerlukan bimbingan bahkan memerlukan pertolongan guru setapak demi setapak. Siswa memerlukan bantuan untuk mengembangkan kemampuannya memahami pengetahuan baru. Walaupun siswa harus berusaha mengatasi kesulitankesulitan yang dihadapi tetapi pertolongan guru tetap diperlukan “.

Dalam mengembangkan model pembelajaran di kelas. Sumantri (2015,hlm.165) menyatakan bahwa 
"Dalam mengajar, guru dapat mengembangkan model mengajarnya yang dimaksudkan sebagai upaya mempengaruhi perubahan baik dalam perilaku siswa, pengembangan modelmodel mengajar tersebut dimaksudkan untuk meningkatkan kemampuanya untuk lebih mengenal siswa dan menciptakan lingkungan yang lebih bervariasi bagi kepentingan belajar siswa."

Mulyasa (2012.hlm.108) menyatakan bahwasannya model pembelajaran Inquiry merupakan salah satu model pembelajaran yang mempersiapkan peserta didik pada situasi untuk melakukan eksperimen sendiri secara luas, melihat apa yang terjadi, ingin melakukan sesuatu, mengajukan pertanyaan, mencari jawaban sendiri, serta menghubungkan penemuan satu dengan penemuan lain.

Eruce dan Weil dalam (Hosnan, 2014,hlm.346) model pembelajaran Inquiry dapat menambah pengetahuan sains, menghasilkan kemampuan berpikir kreatif, keterampilan serta dalam memperoleh suatu data atau konsep. Sedangkan Nasution (2005,hlm.128), menyatakan bahwa model pembelajaran Inquiry adalah merupakan proses belajar yang memberikan kesempatan pada siswa untuk menguji dan menafsirkan problema secara sistematika yang memberikan konklusi berdasarkan pembuktian.

Sanjaya,(2006,hlm.43) menambahkan bahwa model pembelajaran inquiry adalah suatu model pembelajaran yang menekankan pada proses berpikir secara kritis dan analitis untuk mencari dan menemukan sendiri jawaban dari suatu permasalahan yang dipertanyakan.

Sebuah model pembelajaran dapat memanfaatkan media pembelajaran dengan tujuan memperlancar proses pelaksanaan tahapan model pembelajaran itu sendiri. Dalam pembelajaran dengan model pembelajaran Inquiry, guru menyajikan bahan berupa media dan sumber ajar untuk dapat membuat siswa menemukan pemahaman secara sendiri dan mandiri.

Dalam pelaksanaannya dalam pembelajaran, perlu diketahui beberapa tahapan (sintax) dari sebuah model pembelajaran. Adapun langkah-langkah model pembelajaran Inquiry menurut Hamdayana (2014,hlm.187) yaitu : 1.) Orientasi Pembelajaran dan pemberian konsep dasar pembelajaran; 2.) Merumuskan masalah; 3.) Merumuskan hipotesis; 4.) Mengumpulkan data; 6.) Menguji hipotesis dengan tindakan pembelajaran; 7.) Merumuskan kesimpulan; Menarik konsep dan kesimpulan umum.

Guru sebagai peneliti pula perlu memahami beberapa prinsip, karakteristik dan menganalisis beberapa hal penting yang mendukung terlaksananya pembelajaran inquiry, baik melalui pemanfaatan sumber belajar, media, strategi pembelajaran ataupun teknik penataan managemen kelas. Untuk itu dalam melaksanakan model pembelajaran Inquiry guru seyogyanya dapat memanfaatkan media pembelajaran sebagai 
salah satu cara untuk melaksanakan model pembelajaran.

Games Book merupakan salah satu media pembelajaran yang di desain dengan tujuan untuk menyampaikan materi melalui konsep permainan. (Rahmat, 2017,hlm.29)

Media alternatif ini menyajikan materi dalam bentuk permainan guna memberikan motivasi para siswa untuk terlibat aktif dalam proses pembelajaran. Permainan tersaji dalam sebuah buku yang di desain berisi berbagai macam permainan yang variatif, dan menantang. Setiap permainan relevan dengan tujuan pembelajaran serta berlandaskan atas standar kompetensi dan kompetensi dasar.

Games Book menyajikan berbagai macam permainan yang disajikan disertai dengan petunjuk penggunaan dan tata cara penyelesaian masalah. Setiap permainan disajikan berbagai persoalan dan pertanyaan terkait materi pembelajaran yang menuntut para siswa terlibat aktif untuk memecahkannya. Pemecahan masalah dilakukan dengan berbagai cara baik dengan cara berkelompok, mandiri ataupun campuran. Pada hakikatnya media ini menuntut adanya kerjasama antar siswa untuk dapat menyelesaikan setiap permainan.

Pada dasarnya media pembelajaran Games Book merupakan penunjang bagi ketatalaksanaan model pembelajaran inquiry untuk dapat mengeskplorasi pengetahuan siswa melalui kegiatan penemuan terstruktur, baik melaui tanya jawab, open endid, penelusuran berdasarkan referensi maupun mengeksplorasi konsep pembelajaran melalui kegiatan langsung.

Fakta dilapangan jauh berbeda bila dibandingkan dengan tuntutan pembelajaran Abad 21 serta harapan pembelajaran Ilmu Pengetahuan Sosial. Fakta pertama berdasarkan hasil pra penelitian melalui observasi dan pengamatan di Kelas IV SD Negeri Karamatjaya Kecamatan Cigalontang Kabupaten Tasikmalaya, terdapat beberapa masalah yang ditemukan di kelas terutama dalam pembelajaran Ilmu Pengetahuan Sosial, salah satunya adalah ketersediaan media pembelajaran dan pemahaman tentang penggunaan model pembelajaran yang variatif pada setiap proses pembelajaran.

Berdasarkan hal tersebut desain pembelajaran yang biasa dilaksanakan dalam pembelajaran Ilmu Pengetahuan Sosial masih berorientasi pada pembelajaran ekspositori dan penugasan. Terlebih pembelajaran Ilmu Pengetahuan Sosial yang lebih banyak menekankan pada konsep dan teori, sehingga membuat para siswa sulit untuk memahami materi pembelajaran yang diajarkan. Misalnya permasalahan yang muncul dari materi pembelajaran Sumber Daya Alam dan pemanfaatannya dalam kehidupan sehari-hari. Materi ini menyajikan berbagai jenis sumber daya alam yang ada di Indonesia, yang langsung secara teks deskripsi melalui tabel memaparkan jenisnya disertai dengan pemanfaatannya dalam kehidupan sehari-hari, tanpa didukung dengan penyajian bentuk gambar-gambar, bentuk sumber daya alam 
dan pemanfaatannya secara variatif, aplikatif dan inovatif. Berdasarkan hal tersebut, banyak siswa yang mengeluhkan untuk sulit memahami, mengetahui dan menghafal berbagai jenis sumber daya alam, macam sumber daya alam dan pemanfaatannya dalam kehidupan sehari-hari.

Persoalan berikutnya selain siswa sulit untuk memahami materi pembelajaran yang disampaikan, ditemukan masih banyak kekurangan yang muncul pada diri siswa, terutama persoalan siswa yang susah diatur, susah bersosialisasi dengan teman berbeda kelompok, kurangnya komunikasi dan kepercayaan diri dalam mengungkapkan pendapat serta masih belum optimalnya kepekaan yang muncul terhadap teman sebayanya ketika proses pembelajaran berlangsung. Berdasarkan temuan masalah tersebut, maka dianalisis bahwa tidak semua siswa mampu menyerap pembelajaran IPS dan mengaplikasikannya dalam proses pembelajaran. Tidak semua siswa mampu membentuk dirinya untuk selalu peka terhadap teman sebayanya, ini terlihat dari pengamatan langsung pada saat proses pembelajaran. Masih terlihat siswa yang mau menang sendiri, susah bergaul, berkomuniaksi, susah menjalin kerjasama dengan siswa lain, kurang menghargai pendapat orang lain, egois, tidak taat aturan, selalu ingin sendiri, selalu ingin dipuji dan banyak hal lainnya yang berkaitan dengan karakter dan keterampilan sosial interpersonal lainya.
Berdasar pada permasalahan kelas yang terjadi, maka perlu adanya tindakan sebagai solusi untuk memecahkan permasalahan dan meningkatkan hasil belajar Ilmu Pengetahuan Sosial.

Berdasarkan beberapa pandangan terkait model pembelajaran dan media pembelajaran yang inovatif dapat memberikan pembelajaran yang bermakna, maka hal ini relevan antara karakteristik siswa sekolah dasar, tuntutan pembelajaran abad 21 serta tujuan pembelajaran IPS yang satu sama lain saling berkesinambungan dengan penerapan model pembelajaran Inquiry dengan memanfaatkan media pembelajaran.

Melalui penerapan model pembelajaran Inquiry diharapkan tujuan pembelajaran dapat tercapai dengan maksimal. Mince Tonda, (2017,hlm.3) menyatakan bahwa model pembelajaran inquiry dapat memberikan peningkatan pada hasil belajar IPS siswa Sekolah Dasar.

Hasil penelitian Dwidayani (2015,hlm.4) menyimpulkan bahwa penerapan model pembelajaran Inquiry dalam proses pembelajaran, dapat meningkatkan hasil belajar siswa pada mata pelajaran IPS pada siswa Sekolah Dasar.

Fatemeh Behjat (2012,hlm.355) dalam hasil penelitiannya menyimpulkan bahwa terdapat perbedaan antara siswa laki-laki dan perempuan dalam hal keterampilan sosial perilaku interpersonal, namun diantara keduanya perlunya adanya motivasi guna untuk mengembangkan interpersonal satu dan 
lainya. Adanya kolaborasi dan kerjasama dalam suatu proses pembelajaran akan memberikan fungsi terhadap kualitas dan hasil pembelajaran yang diharapkan.

Ana Maria Suduc (2015,hlm.321) dalam penelitiannya berjudul "Inquiry Based Science Learning in Primary Education" menyimpulkan hasil penelitiannya bahwa

The fact that $20 \%$ of the students would participate in their ideal Science lesson only fairly often, sometimes or rarely, proves once again that it's a necessity to change the approach in Science lessons in order to increase students' interest. The findings of this study show that for primary school level students it is important to participate to enjoyable Science lessons, to understand the subject matter, to participate to Science lessons that are useful in their everyday life, etc. Overall, the IBSE Science lessons proved to be more enjoyable and relevant, from different aspects, for young students than usual Science lessons.

Temuan hasil penelitian Arsaythamby Veloo (2013,hlm.143) dalam penelitiannya terhadap 149 siswa yang berjudul "Inquirybased instruction, students' attitudes and teachers' support towards science achievement in rural primary schools", Hasil penelitian menyimpulkan bahwa

The results indicated that female students perform better in science than male students. In addition, the regression results revealed that all three independent variables, namely Inquiry-based instruction, students' attitudes toward science and teachers' support significantly influence science achievement among year five students. It was clear that the findings of this study have important implications for primary school students, specifically in evaluating science achievement.

Berdasar hasil penelitian tersebut maka dapat disimpulkan bahwa terdapat hubungan antara model pembelajaran Inquiry, sikap siswa terhadap sains dan dukungan guru terhadap prestasi sains.

Hal ini menunjukkan bahwa penelitiannya mengenai pembelajaran Inquiry di Sekolah Dasar memberikan partisipasi aktif siswa terhadap pembelajaran dan disukai banyak siswa karena membuat pembelajaran lebih menyenangkan.

Supardi (2015,hlm.2) menyatakan bahwa hasil belajar pada dasarnya adalah terjadinya proses perubahan tingkah laku dari tidak tahu menjadi tahu, dari sikap yang kurang baik menjadi lebih baik, dan dari yang tidak terampil menjadi terampil.

Hasil belajar dapat membantu siswa untuk memecahkan permasalahan dalam hidupnya serta dapat menyesuaikan diri dengan lingkungan menuju perubahan kearah yang lebih positif. Pada prinsipnya hasil belajar merupakan suatu cerminan terhadap kemampuan individu setelah adanya proses pembelajaran. Bentuk hasil yang diperoleh dapat berupa angka, sikap dan keterampilan.

Bloom menjabarkan tipe hasil belajar terbagi atas 3 ranah yakni kognitif, afektif dan psikomotorik.Hasil belajar kognitif berhubungan dengan prestasi belajar siswa berupa pengetahuan, afektif lebih menekankan pada aspek sikap dan psikomotorik lebih menekankan pada aspek 
keterampilan. (Supardi, 2015,hlm.2)

Berdasarkan pandangan tersebut dapat disimpulkan bahwasannya hasil belajar tidak mengarah pada satu aspek saja, melainkan 3 aspek yang satu sama lain harus diperhatikan dalam proses pembelajaran. Dalam penelitian ini, peneliti lebih memfokuskan hasil belajar aspek kognitif yang diukur melalaui tes hasil belajar dan aspek afektif yang diukur dengan domain konatif yang fokus pada keterampilan sosial siswa.

Chaplin, dalam (Yulia,2011,hlm.5) menyatakan bahwa keterampilan sosial merupakan bentuk perilaku, perbuatan dan sikap yang ditampilkan oleh individu ketika berinteraksi dengan orang lain disertai dengan ketepatan dan kecepatan sehingga memberikan kenyamanan bagi orang yang berada disekitarnya. Senada dengan apa yang dikemukakan tersebut, (Gresham \& Elliott, 1990,hlm.6) yang mendefinisikan keterampilan sosial sebagai "Socially acceptable learned behaviors that enable an individual to interact effectively with others and to avoid or escape negative social interactions with others".

Lebih lanjut, Singleton (1983,hlm.283) menyatakan bahwasannya "social skills are closely related to the relationship of communication with others. There is evidence that communication has occurred when the recipient changed it behavior or attitude".

Pandangan ini mengidentifikasikan keterampilan sosial kedalam bentuk perilaku interpersonal yang mencakup kemampuan individu untuk menjalin hubungan sosial dengan orang-orang di sekitarnya. Perilaku interpersonal yang dimaksud merupakan cerminan perilaku individu dalam memahami orang lain dalam konteks interaksi sosial. Hal ini sejalan dengan apa yang dikemukakan oleh Greene (James Freeman, 2015,hlm.51) yang menyatakan bahwa

"Social skills lead to interpersonal behavior requiring complex communication skills of the younger generation, including interpreting social cues, recognizing how behaviors affect others, and understanding how one feels for others".

Anderman, (2009,hlm.3) mempertegas tentang keterampilan sosial yang menyatakan bahwa

"A large amount of evidence supports the role that children's social skills (including interpersonal behavior and learning-related skills) play in social and academic success.In general, children's interpersonal skills associated with social interaction include the ability to collaborate, communicate, social interaction and establish relationships with other individuals, whereas learning-related skills have predicted academic.interpersonal skills are essential for social adjustment in childhood and adolescence.For example, one study found that poor interpersonal skills (eg, externalization problems) in childhood , predicts an academic problem in adolescence, which in turn causes internal problems in adulthood.

Gimpel \& Merrel (1998,hlm.1) mengkarakteristikan keterampilan sosial sosial sebagai “....social skills are learned, composed of specific behaviors, include initiations and responses, maximize social reinforcement, are interactive and situationspecific, and can be specified as targets for 
intervention",.

Berdasar karakteristik keterampilan sosial yang dikemukakan, maka untuk mempermudah mengenal dan memahami keterampilan sosial dalam proses pembelajaran perlu diketahui apa saja unsur yang ada dalam keterampilan sosial.

Sharon dan Simpson (2010,hlm.3) menyatakan bahwa "Social skills are behaviors that promote positive interaction with others and the environment. Some of these skills include showing empathy, participation in group activities, generosity, helpfulness, communicating with others, negotiating, and problem solving”.

Pendapat tersebut senada dengan apa yang dikemukakan oleh Seefeldt dan Barbour (1994) dalam (Putri Admi,2013,hlm.337) yang menjelaskan keterampilan sosial terdari dari keterampilan komunikasi, berbagi (sharing), bekerja sama dan berpartisipasi dalam kelompok masyarakat. Selain dari itu, Sharon dan Simpson (2010,hlm.3 ) menjelaskan lebih rinci mengenai batasan yang ada dalam keterampilan sosial, sebagaimana pernyataannya bahwa:

"Social skills are behaviors that promote positive interaction with others and the environment. Some of these skills include showing empathy, participation in group activities, generosity, helpfulness, cooperation, communicating with others, negotiating, and problem solving".

Gresham \& Elliot (1990,hlm.87) lebih lanjut menyatakan “...Major categories of social skill is communication, cooperation, assertion, responsibility, empathy, engagement dan self control."

Berdasarkan berbagai pandangan terkait unsur keterampilan sosial yang dikemukakan, maka terdapat beberapa kesamaan yang menjadi fokus dari keterampilan sosial. Peneliti menetapkan unsur keterampilan pandangan Sharon dan Simpon yang akan dijadikan aspek pengamatan keterampilan sosial.

Berdasarkan pendapat tersebut, keterampilan sosial erat kaitanya dengan perilaku interpersonal yang ditunjukan seseorang kepada individu lainya. Perilaku interpersonal ini memerlukan kemampuan untuk komunikasi yang dijadkan sebagai isyarat sosial, interaksi sosial, mengenali bagaimana perilaku, mempengaruhi orang lain, dan memahami bagaimana perasaan orang lain. Dengan demikian keterampilan sosial mengarah pada kemampuan individu untuk dapat melakukan komunikasi, interaksi, memahami perasaan orang lain serta menjalin kerjasama dengan individu lain. Keterampilan sosial diartikan sebagai keterampilan individu disertai dengan kecakapan dan keterampilan yang dimiliki anak dalam memulai aktivitas ataupun mempertahankan suatu hubungan yang positif dalam berinteraksi secara sosial dalam bentuk perilaku interpersonal yang dimana seseorang harus bisa berkolaborasi, berkomunikasi, berinteraksi sosial. dan membangun hubungan dengan orang lain.

Oleh karena itu, perlu adanya penerapan model pembelajaran yang inovatif dalam pembelajaran IPS yang diharapkan akan 
meningkatkan hasil belajar siswa serta menciptakan kondisi belajar yang lebih efektif, efisien dan menyenangkan, memberikan kesempatan kepada siswa untuk berperan serta aktif bertukar informasi dalam kegiatan kelompok, memiliki kepekaan terhadap lingkungan sosial, mampu bekerjasama dan bertanggung jawab.

\section{METODE}

Dalam Penelitian ini peneliti menggunakan metode penelitian tindakan

(action research) dengan batasan kelas atau classroom action research dengan menggunakan model Kemmis dan Mc Taggart. Penelitian tindakan ini dilakukan dalam dua siklus. Setiap siklus terdiri dari tahapan perencanaan, tindakan, observasi dan refleksi. Metode penelitian action research ini dilaksanakan untuk meningkatkan hasil belajar Ilmu Pengetahuan Sosial materi sumber daya alam dan pemanfaatannya.

Adapun populasi dalam penelitian ini adKaramatjaya Kecamatan Cigalontang Kabupaten Tasikmalaya berjumlah 20 orang yakni 10 orang laki-laki dan 10 orang perempuan. Instrumen penelitian terdiri lembar observasi pengamatan perilaku, tes hasil belajar dan dokumentasi.

\section{HASIL DAN PEMBAHASAN}

Hasil penelitian ini berhubungan dengan peningkatan hasil belajar Ilmu Pengetahuan Sosial materi sumber daya alam dan pemanfaatannya pada kelas IV SD Ngeri Karamatjaya Kecamatan Cigalontang Kabupaten Tasikmalaya. Diadakannya penelitian ini, bertujuan untuk melihat peningkatan tes hasil belajar Ilmu Pengetahuan Sosial dan hasil observasi pengamatan perilaku keterampilan sosial setelah dilakukannya tindakan pada siswa kelas IV SD Negeri Karamatjaya Kecamatan Cigalontang Kabupaten Tasikmalaya.

Hasil analisis data diperoleh bahwa aktivitas guru dan siswa meningkat setiap siklus. Rata-rata tes hasil belajar IPS pada pra tindakan dengan nilai 70,45, siklus I dengan nilai 74.45 dan siklus II dengan nilai rata-rata 88. Persentase ketuntasan dari pra tindakan sebesar $30 \%$ meningkat pada siklus II menjadi $100 \%$ tuntas dengan persentase peningkatan sebesar $70 \%$. Rata-rata hasil observasi pengamatan perilaku keterampilan sosial 2 siklus menunjukan terdapat peningkatan dan perubahan dari siklus I pertemuan pertama dengan skor 8 atau $26,66 \%$, siklus I pertemuan kedua dengan skor 11 atau $36,66 \%$, siklus II pertemuan pertama 17 atau $56,66 \%$, dan siklus II pertemuan kedua dengan skor rata-rata 25 atau $83,33 \%$.Persentase ketuntasan dari pra tindakan 0 atau $0 \%$ menjadi 18 orang yang tuntas atau $90 \%$ tuntas pada siklus II pertemuan kedua dengan persentase peningkatan sebesar $90 \%$.

Untuk melihat secara jelas mengenai peningkatan tes hasil belajar dan skor keterampilan sosial siswa pada proses pembelajaran Ilmu Pengetahuan Sosial materi sumber daya alam dan pemanfaatannya disajikan dalam analisis data berikut. 


\section{a) Analisis Data Tes Hasil Belajar}

Hasil analisis data tes hasil belajar siswa pada pra tindakan, siklus I dan siklus II disajikan dalam tabel 1 berikut.

Tabel 1

Analisis Data Tes Hasil Belajar Siswa pada Pra tindakan, Siklus I dan Siklus II

\begin{tabular}{|c|c|c|c|c|c|c|}
\hline \multirow{2}{*}{ NO } & \multirow{2}{*}{$\begin{array}{c}\text { Aspek } \\
\text { Pembanding }\end{array}$} & \multirow{2}{*}{$\begin{array}{c}\text { Pra } \\
\text { Tindakan }\end{array}$} & \multirow{2}{*}{$\begin{array}{c}\text { Siklus } \\
\text { I }\end{array}$} & \multirow{2}{*}{$\begin{array}{c}\text { Siklus } \\
\text { II }\end{array}$} & \multicolumn{2}{|c|}{ Peningkatan } \\
\hline & & & & & $\begin{array}{l}\text { Nilai/ } \\
\text { Skor }\end{array}$ & Persentase \\
\hline 1. & $\begin{array}{l}\text { Nilai rata- } \\
\text { rata kelas }\end{array}$ & 70,45 & 74.45 & 88 & 17,55 & $24,91 \%$ \\
\hline 2. & $\begin{array}{l}\text { Nilai } \\
\text { terendah }\end{array}$ & 55 & 65 & 79 & 24 & $43,63 \%$ \\
\hline 3. & $\begin{array}{l}\text { Nilai } \\
\text { tertinggi }\end{array}$ & 79 & 82 & 98 & 19 & $24,05 \%$ \\
\hline 4. & Tuntas & 6 & 9 & 20 & 14 & $70 \%$ \\
\hline
\end{tabular}

Berdasar tabel 1 tentang analisis data tes hasil belajar siswa mulai dari pra tindakan, siklus I dan siklus II, maka didapatkan data bahwa pada pra tindakan yang memiliki nilai rata-rata kelas 70,45 pada saat siklus II menjadi rata-rata nilai sebesar 88 , hal ini membuktikan adanya peningkatan yang cukup besar yakni berkisar 17,55 atau $24,91 \%$. Untuk aspek nilai terendah pada pra tindakan yang menunjukkan nilai 55 dan pada saat siklus II menjadi 79, hal ini membuktikan adanya peningkatan sebesar 24 atau 43,63\%. Untuk aspek nilai tertinggi pada saat pra tindakan dengan nilai 79, maka pada siklus II menjadi 98, hal ini menunjukkan adanya peningkatan yang cukup besar yakni 19 atau 24,05\%. Untuk aspek ketuntasan, pada pra tindakan yang menunjukkan siswa yang tuntas sebanyak 6 orang, maka pada siklus II menunjukkan ketuntasan secara maksimal yakni seluruh siswa sebanyak 20 orang atau $100 \%$ dikategorikan tuntas.

Untuk memperjelas peningkatan aspek nilai rata-rata kelas, nilai tertinggi dan nilai ter rendah, maka masing-masing aspek maka digambarkan dalam bentuk grafik 1 berikut.

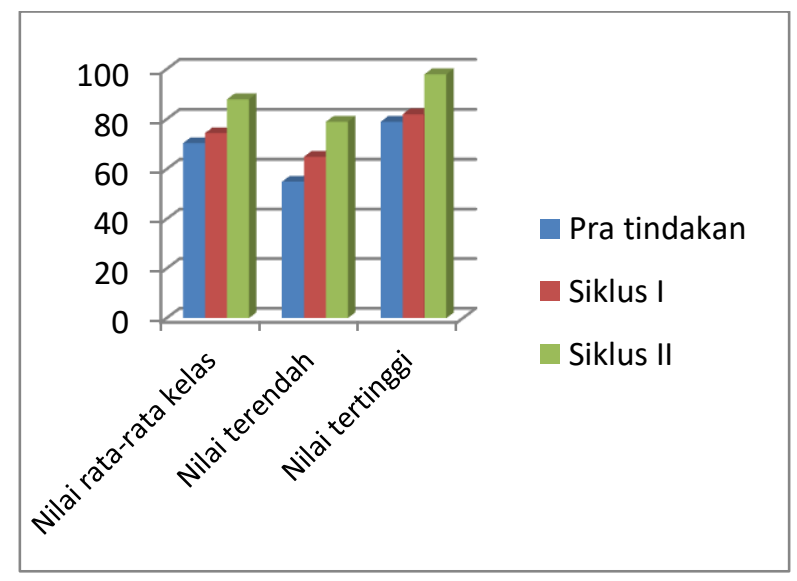

\section{Grafik 1 Peningkatan Tes Hasil Belajar Siswa Berdasarkan Analisis Data Pra tindakan, Siklus I dan Siklus II}

Berdasarkan grafik 1 terlihat jelas bahwasanya peningkatan tes hasil belajar siswa baik aspek rata-rata kelas pada tiap siklus, nilai terendah dan nilai tertinggi pada setiap siklusnya. Kesimpulannya, tes hasil belajar siswa berdasarkan tes hasil belajar pembelajaran Ilmu Pengetahuan Sosial materi sumber daya alam dan pemanfaatannya, menunjukkan peningkatan yang sangat signifikan dan melampaui kriteria ketuntasan minimal yang ditetapkan. Berdasarkan data tersebut dinyatakan bahwa tes hasil belajar siswa kelas IV SD Negeri Karamatjaya Kecamatan Cigalontang Tasikmalaya pada pembelajaran Ilmu Pengetahuan Sosial materi sumber daya alam dan pemanfaatannya dinyatakan tuntas pada siklus II pertemuan kedua.

Selanjutnya, untuk menggambarkan analisis data aspek ketuntasan siswa pada pra tindakan, siklus I dan siklus II maka 
digambarkan dalam bentuk grafik 2 berikut.

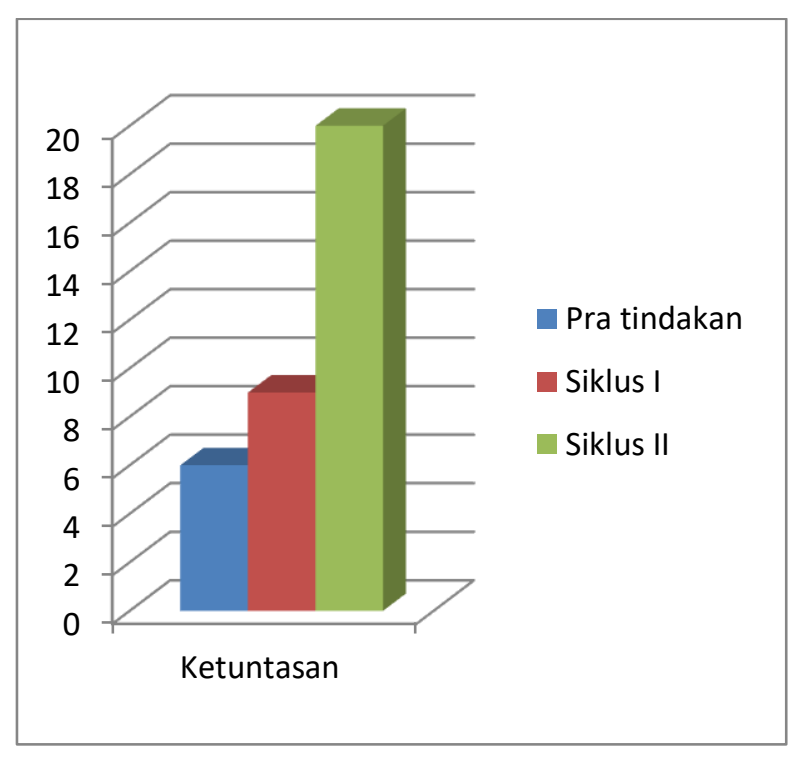

\section{Grafik 2 Analisis Data Ketuntasan Tes Hasil Belajar Siswa pada Pra tindakan, Siklus I dan Siklus II}

Berdasarkan grafik 2 dapat terlihat secara jelas peningkatan ketuntasan tes hasil belajar siswa mulai dari pra tindakan sebanyak 6 orang atau $30 \%$ dari jumlah keseluruhan siswa yang tuntas, siklus I sebanyak 9 orang atau $45 \%$ siswa yang tuntas serta siklus II sebanyak 20 orang atau $100 \%$ dari keseluruhan siswa dinyatakan tuntas pada pembelajaran Ilmu Pengetahuan Sosial materi sumber daya alam dan pemanfaatannya melalui penerapanmodel pembelajaran Inquiry berbantuan media Games Book di kelas IV SD Negeri Karamatjaya Kecamatan Cigalontang Tasikmalaya.

\section{b) Analisis Data Hasil Observasi}

\section{Pengamatan Keterampilan Sosial}

Hasil analisis data hasil belajar (afektif) keterampilan sosial siswa pada saat pra tindakan, siklus I dan siklus II disajikan dalam tabel 2 berikut.

Tabel 2 Analisis Data Hasil Observasi Pengamatan Keterampilan Sosial pada Pra tindakan,
Siklus I dan Siklus II

\begin{tabular}{|c|c|c|c|c|c|c|c|c|}
\hline \multirow{3}{*}{ NO } & \multirow{3}{*}{$\begin{array}{c}\text { Aspek } \\
\text { Pembanding }\end{array}$} & \multirow{3}{*}{$\begin{array}{c}\text { Pra } \\
\text { Tindakan }\end{array}$} & \multirow{2}{*}{\multicolumn{2}{|c|}{ Siklus I }} & \multirow{2}{*}{\multicolumn{2}{|c|}{$\begin{array}{c}\text { Siklus } \\
\text { II }\end{array}$}} & \multicolumn{2}{|c|}{ Peningkatan } \\
\hline & & & & & & & \multirow{2}{*}{$\begin{array}{l}\text { Nilai/ } \\
\text { Skor }\end{array}$} & \multirow{2}{*}{$\begin{array}{l}\text { Persent } \\
\text { ase }\end{array}$} \\
\hline & & & P.1 & P.2 & P.1 & P.2 & & \\
\hline 1. & $\begin{array}{l}\text { Skor rata- } \\
\text { rata kelas }\end{array}$ & 6 & 8 & 11 & 17 & 25 & 19 & $31,66 \%$ \\
\hline 2. & $\begin{array}{l}\text { Skor } \\
\text { terendah }\end{array}$ & 3 & 5 & 7 & 9 & 20 & 17 & $56,66 \&$ \\
\hline 3. & $\begin{array}{l}\text { Skor } \\
\text { tertinggi }\end{array}$ & 8 & 10 & 15 & 21 & 29 & 21 & $26,20 \%$ \\
\hline 4. & Tuntas & 0 & 0 & 9 & 14 & 18 & 18 & $90 \%$ \\
\hline
\end{tabular}

Keterangan : P.1 = Pertemuan pertama P. 2 = Pertemuan kedua

Berdasar tabel 2 tentang analisis data hasil observasi pengamatan keterampilan siswa mulai dari pra tindakan, siklus I dan siklus II, maka didapatkan data bahwa pada pra tindakan yang memiliki skor rata-rata kelas 6, dan pada saat siklus II pertemuan kedua menjadi rata-rata skor sebesar 25 , hal ini membuktikan adanya peningkatan yang cukup besar yakni berkisar 19 atau 31,66\%. Untuk aspek nilai terendah pada pra tindakan yang menunjukkan rata-rata skor 3 dan pada saat siklus II pertemuan kedua menjadi 20, hal ini membuktikan adanya peningkatan skor keeterampilan sosial sebesar 17 atau 56,66\%. Untuk aspek nilai tertinggi pada saat pra tindakan dengan skor 8 , maka pada siklus II pertemuan kedua menjadi 29, hal ini menunjukkan adanya peningkatan yang cukup besar yakni 19 atau 26,20\%. Untuk aspek ketuntasan, pada pra tindakan yang belum menunjukkan siswa yang memenuhi kriteria skor ketuntasan keterampilan sosial, namun pada siklus II pertemuan kedua siswa yang tuntas seluruhnya sebanyak 20 orang atau 100 dikategorikan tuntas.

Untuk memperjelas peningkatan aspek 
nilai rata-rata kelas, nilai tertinggi dan nilai ter rendah, maka masing-masing aspek maka digambarkan dalam bentuk grafik 3 berikut.

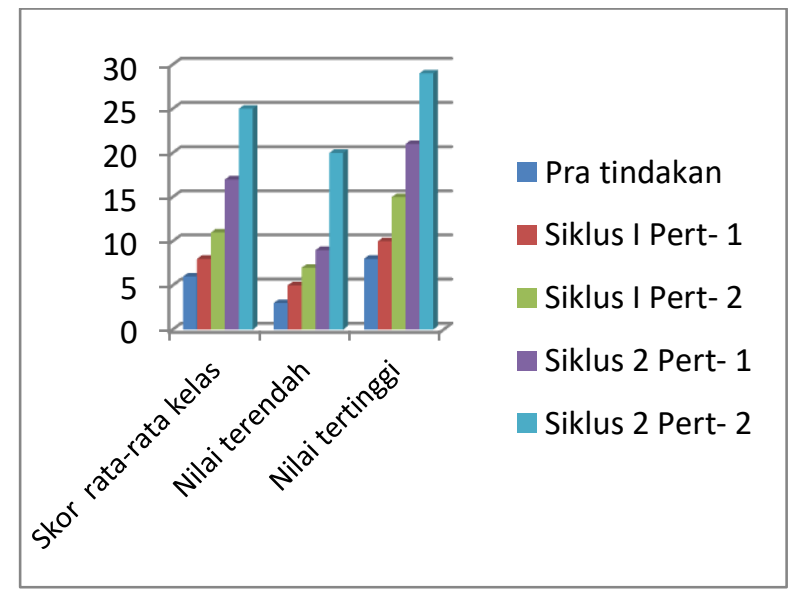

\section{Grafik 3 Analisis Data Hasil Observasi Pengamatan Keterampilan Sosial pada Pra tindakan, Siklus I dan Siklus II}

Berdasarkan grafik 3 terlihat jelas bahwasanya peningkatan hasil belajar afektif keterampilan sosial siswa baik aspek ratarata kelas pada tiap siklus, skor terendah dan skor tertinggi pada setiap siklusnya. Kesimpulannya, hasil belajar belajar afektif keterampilan sosial siswa berdasarkan hasil observasi pengamatan perilaku keterampilan sosial pada proses pembelajaran Ilmu Pengetahuan Sosial materi sumber daya alam dan pemanfaatannya, menunjukkan peningkatan yang sangat signifikan dan melampaui skor minimal yang ditetapkan. Berdasarkan data tersebut dinyatakan bahwa hasil belajar afektif keterampilan sosial siswa kelas IV SD Negeri Karamatjaya Kecamatan Cigalontang Tasikmalaya pada pembelajaran Ilmu Pengetahuan Sosial materi sumber daya alam dan pemanfaatannya dinyatakan tuntas pada siklus II pertemuan kedua.

Selanjutnya, untuk menggambarkan peningkatan aspek ketuntasan siswa hasil observasi pengamatan perilaku keterampilan sosial pada pra tindakan, siklus I dan siklus II maka digambarkan dalam bentuk grafik 4 berikut.

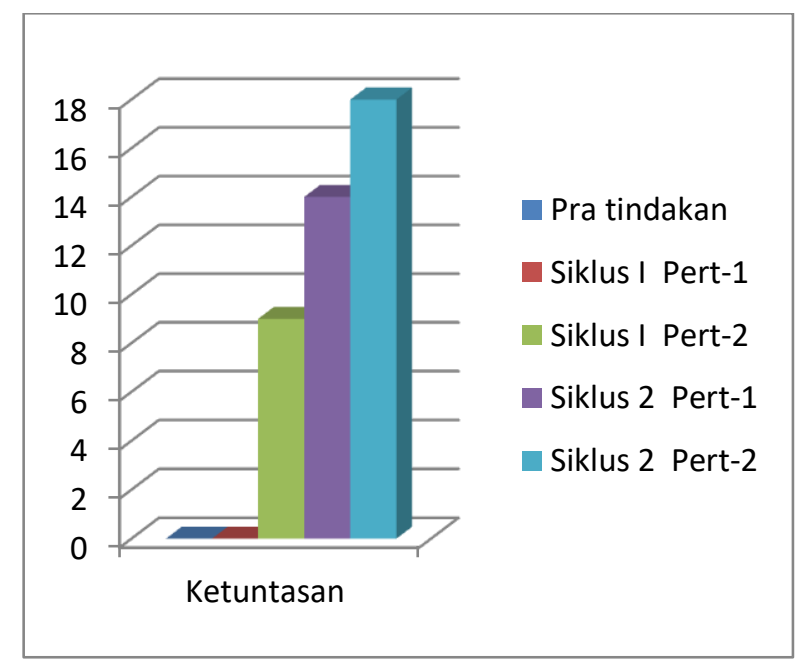

\section{Grafik 4 Analisis Data Hasil Observasi Pengamatan Keterampilan Sosial pada Pra tindakan, \\ Siklus I dan Siklus II}

Berdasarkan grafik 4 dapat terlihat secara jelas peningkatan ketuntasan hasil belajar afektif keterampilan siswa pada proses pembelajaran mulai dari pra tindakan dan siklus I pertemuan pertama yang masih belum ada siswa yang memperoleh skor minimal ketuntasan keterampilan sosial, siklus I pertemuan kedua sebanyak 9 orang atau $45 \%$ yang mencapai ketuntasan, siklus II pertemuan pertama sebanyak 14 orang atau $70 \%$ yang menunjukkan skor ketuntasan keterampilan sosial serta pada siklus II pertemuan kedua sebanyak 18 orang atau 90\% dari keseluruhan siswa dinyatakan tuntas menunjukkan keterampilan sosial pada proses pembelajaran Inquiry berbantuan media

\section{Games Book.}

Berdasarkan kedua data ketuntasan tes hasil belajar yang bersumber dari tes hasil 
belajar Ilmu Pengetahuan Sosial materi sumber daya alam dan pemanfaatannya, dan ketuntasan hasil belajar afektif yang bersumnber dari data hasil observasi pengamatan perilaku pada saat proses pembelajaran pembelajaran Ilmu Pengetahuan Sosial materi sumber daya alam dan pemanfaatannya, maka dapat ditarik kesimpulan bahwa hasil belajar siswa kelas IV SD Negeri Karamatjaya Kecamatan Cigalontang Tasikmalaya kognitif dinyatakan tuntas $100 \%$ dari total jumlah siswa dan hasil belajar afektif dinyatakan tuntas $90 \%$ dari total jumlah siswa keseluruhan. Berdasarkan hal tersebut, apabila merujuk pada target penelitian yang menetapkan minimal $80 \%$ dinyatakan tuntas, maka penelitian peningkatan hasil belajar Ilmu Pengetahuan Sosial materi sumber daya alam dan pemanfaatannya melalui model Inquiry berbantuan media Games Book di kelas IV SD Negeri Karamatjaya Kecamatan Cigalontang Taikmalaya dinyatakan tuntas dan berhasil.

\section{c.) Pembahasan Ketuntasan Hasil Belajar IPS per siswa melalui Model} Pembelajaran Inquiry di Kelas IV SD Negeri Karamatjaya Kecamatan

\section{Cigalontang Tasikmalaya}

Untuk medeskripsikan peningkatan dan ketuntasan tes hasil belajar dan keterampilan sosial Ilmu Pengetahuan Sosial materi Sumber Daya Alam dan Pemanfaatannya di kelas IV SD Negeri Karamatjaya Kecamatan Cigalontang
Tasikmalaya secara umum maka disajikan dalam Grafik 5 dan Grafik 6 berikut.

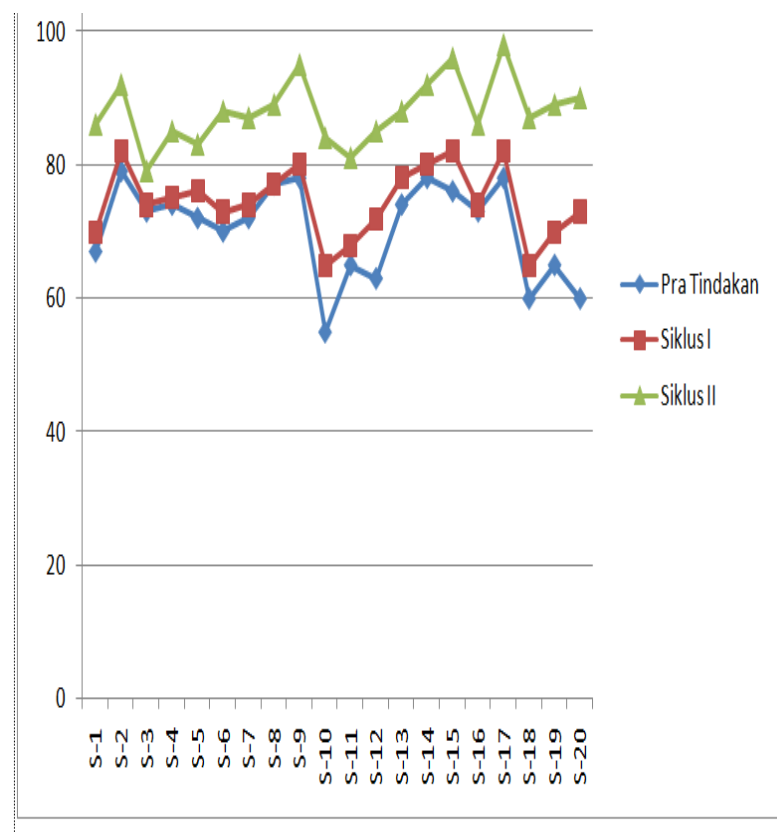

\section{Grafik 5 Peningkatan Ketuntasan Tes Hasil Belajar Seluruh Siswa pada pra tindakan, Siklus I dan Siklus II}

Berdasarkan grafik 5 mengenai peningkatan ketuntasan tes hasil belajar seluruh siswa pada pra tindakan, siklus I dan siklus II, maka disimpulkan bahwa tes hasil belajar siswa terhadap materi Sumber Daya Alam dan Pemanfaatannya dinyatakan tuntas $100 \%$ dengan peningkatan yang sangat signifikan. Selanjutnya, untuk menggambarkan hasil observasi pengamatan perilaku keterampilan sosial siswa pada saat proses pembelajaran Ilmu Pengetahuan Sosial materi Sumber Daya Alam dan Pemanfaatannya, maka disajikan dalam tabel 6 berikut. 


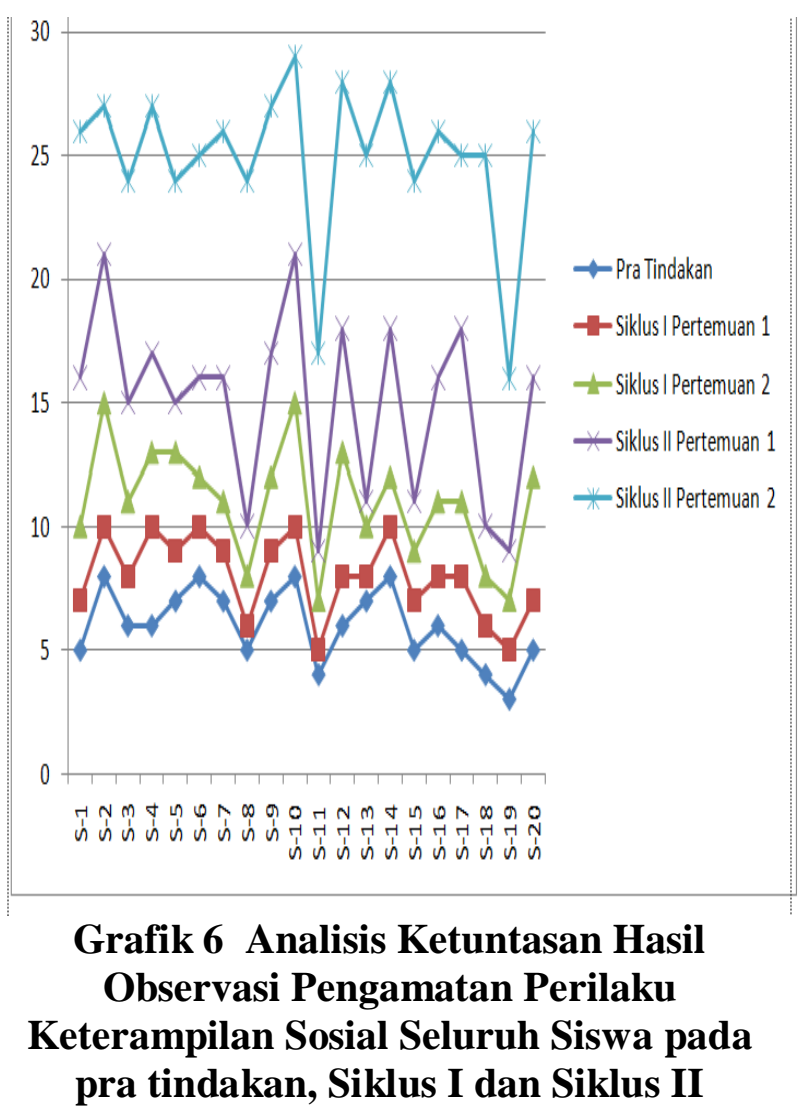

Berdasarkan grafik 6 tentang hasil observasi pengamatan perilaku keterampilan sosial seluruh siswa pada pra tindakan, siklus I dan siklus II, maka disimpulkan secara umum seluruh siswa mengalami peningkatan skor keterampilan sosial per pertemuan. Meskipun dalam konteksnya masih ada 2 orang siswa yang memperoleh skor dibawah kriteria ketuntasan minimal keterampilan sosial.

Keberhasilan peningkatan hasil belajar Ilmu Pengetahuan Sosial materi sumber daya alam dan pemanfaatannya, tidak lepas dari faktor yang ikut mendukung peningkatan hasil belajar siswa. Djaramah(2007,hlm.39) menyatakan bahwa Berhasil atau tidaknya seseorang dalam belajar disebabkan oleh faktor yang berasal dari dalam diri individu dan faktor dari luar individu.
Syah

(Syarifudin,2004,hlm.38)

mengemukakan

beberapa faktor yang mempengaruhi belajar meliputi:

1) Faktor internal (faktor dari dalam siswa), yakni kondisi jasmani dan rohani siswa;

2) Faktor eksternal (faktor dari luar siswa), yakni kondisi lingkungan di sekitar siswa meliputi keluarga, guru dan cara mengajarnya, alat-alat yang dipengaruhi dalam belajar mengajar,media,model pembelajaran lingkungan dan kesempatan yang tersedia".

Berdasarkan pandangan tersebut, peran model pembelajaran, media pembelajaran, kesempatan yang tersedia, serta faktor guru dengan teknik mengajarnya menjadikan salah satu faktor yang ikut menentukan keaktifan siswa dalam proses pembelajaran. Keselman (2003,hlm.47-61) menyatakan bahwa Inquirybased learning is an educational strategy in which students follow methods and practices similar to those of professional scientists in order to construct knowledge. Selain dari itu Anderson (2012,hlm.9) mempertegas dengan pendapatnya yang menyatakan bahwa Inquiry refers to a learning process in which students are engaged. It is said to be an active learning process something that students do, not something that is done to them.

Berdasarkan pandangan ahli tersebut pada hakikatnya model pembelajaran Inquiry dapat membangun pengetahuan disertai dengan pembelajaran yang berproses sehingga dapat membentuk hubungan yang baik antar siswa. selin dari itu Carol C 
Kuhthau (2007,hlm.2) lebih merinci peranan model pembelajaran Inquiry terhadap siswa yang menyatakan bahwa Guided Inquiry instructional teams help students develop research competency and subject knowledge as well as foster motivation, reading comprehension, language development, writing ability, cooperative learning, and social skills.

Selanjutnya selain peran model pembelajaran Inquiry dalam meningkatkan aktivitas dan keterampilan sosial siswa, faktor media pun sangat berpengaruh pada keaktifan siswa dan keterampilan sosial siswa dalam proses pembelajaran. hal ini sesuai dengan apa yang dikemukakan oleh Sagala (2012,hlm.170) yang menyatakan bahwa

"Model pembelajaran yang tepat untuk bahan pelajaran tertentu dapat lebih efektif jika disertai dengan media pendidikan yang tepat pula. Pada dasarnya perkembangan siswa sebagai anak, pengajaran lebih mengutamakan sifat konkret, sehingga alat mengajarpun dimulai pemilihannya dari sifat itu seperti yang digambarkan sebuah kerucut yang bertingkat yang sifatnya mulai dari yang paling abstrak sampai yang paling konkret jika dilihat dari atas kebawah".

Pada penelitian ini, penerapan model pembelajaran Inquiry dibantu dengan media Games Book. Ahmed Yousif (2005,hlm.65) menyatakan bahwa " ... The instructional media add elements of reality by providing such concrete examples". Pada hakikatnya media pembelajaran merupakan salah satu alat untuk menyampaikan informasi melalui sebuah benda yang dapat mengkonkritkan sesuatu yang abstrak menjadi dapat dilihat dan dipahami. Senada dengan pernyataan tersebut.

Piaget (1950,hlm.31) menyatakan bahwa siswa sekolah dasar berada pada tahapan perkembangan operasional konkret. Selain dari itu, Sumantri (2015,hlm.153-154) menyatakan bahwa karakteristik siswa sekolah dasar meliputi (1).Senang Bermain, (2).Senang Bergerak; (3).Siswa senang bekerja kelompok; dan (4). Senang merasakan atau melakukan/ memperagakan sesuatu secara langsung.

Pada prinsipnya, proses pembelajaran yang melibatkan pengalaman siswa serta memberikan pembelajaran yang nyata, dapat memberikan peranan terhadap daya ingat dan kemampuan memahami yang kuat terhadap sesuatu yang dialami. Proses pembelajaran yang melibatkan siswa dalam belajar akan mampu meningkatkan kreatifitas dan kemampuan berfikir untuk melakukan tindakan dan upaya memecahkan apa yang dihadapi di lapangan. Selain dari itu, proses pembelajaran yang demikian, akan meningkatkan rasa solid antar siswa, kerjasama, kedisiplinan, mandiri dan kekompakan dalam kelompok belajar.

\section{SIMPULAN}

Berdasarkan data-data yang terhimpun melalui analisis data kualitatif dan kuantitatif maka dapat disimpulkan bahwa pelaksanaan tindakan model pembelajaran Inquiry berbantuan media Games Book memberikan peningkatan terhadap tes hasil belajar IPS 
dan Keterampilan Sosial siswa pada pembelajaran Ilmu Pengetahuan Sosial. Hal ini terbukti dengan melihat nilai rata-rata dari setiap siklus dan terus mengalami peningkatan sampai melebihi batas kriteria ketuntasan minimal.

Implikasi diadakannya penelitian dengan menggunakan model pembelajaran Inquiry berbantuan media Games Book terhadap pasrtisipan yaitu, adanya peningkatan hasil belajar IPS dan Keterampilan Sosial siswa pada pembelajaran pembelajaran Ilmu Pengetahuan Sosial baik melalui pemahaman, sikap, dan keterampilan siswa dalam proses pembelajaran.

Meningkatnya hasil belajar IPS dan Keterampilan Sosial siswa dapat dilihat dari peningkatan data per siklus pembelajaran.Dengan demikian pada penelitian ini hasil belajar yang ditetapkan dapat tuntas dan permasalahan dapat dipecahkan sesuai dengan harapan

\section{REFERENSI}

Ahmed Yousif, dkk. Utilisation and Benefits of Instructional Media in Teaching Social Studies Courses as Perceived by Omani Students. Malaysian Online Journal of Instructional Technology, ISSN: 1823-1144 Volume 2, No. 1, April 2005.

Ana Maria Suduc. Inquiry Based Science Learning in Primary Education, Jurnal Online :Elsevier, Procedia - Social and Behavioral Sciences Vol 205 (2015) 474 -479, ISSN1327-0428 @ 2015.

Anderson. Reforming Science Teaching: What Research says about Inquiry. Journal of Science Teacher Education, 13(1): 1-12, 20021 (C2002 Kluwer Academic
Publishers, Printed in the NetherlandsColorado.

Arsaythamby Veloo. Inquiry-based instruction, students' attitudes and teachers' support towards science achievement in rural primary schools, Jurnal Online :Elsevier, Procedia Social and Behavioral Sciences Vol 93 (2013) 65 - 69, ISSN1132-0528 (C) 2013.

Carol C Kuhthau.2007.Guided Inquiry : Learning in the 21 st Century School. London: Libraries Unlimited.

DEPDIKNAS. Permendikbud Nomor 24 Tahun 2006 tentang Pelaksanaan Permendikbud No. 22 Tahun 2006 dan 24 Tahun 2006.Jakarta:DEPDIKNAS.

Fatemeh Behjat. Interpersonal and intrapersonal intelligences: Do they really work inforeign-language learning?.Jurnal Online : Elsevier, Procedia - Social and Behavioral Sciences Vol.32 (2012) P.355. 18770428 @ 2011 Published by Elsevier Ltd.
Hamdayana.(2014).Model dan Metode Pembelajaran Kreatif dan Berkarakter.Bogor:Ghalia Indonesia.

Hosnan. (2014). Pendekatan Saintifik dan Kontekstual dalam pembelajaran abad 21. Bogor: Ghalia Indonesia.

James Freeman. Developing Social Skills and Relationships. Reclaimingjournal.

Winter,2015 Volume 23, number 4, h.51.

Jarolimek,J.1977.Social Studies in Elementary Education.New York: Macmillan Publishing Co.,Inc

Jhoni L Matson (2009). Social Behavior and Skills in Children. New York Dordrecht Heidelberg London: Springer.

M. Anderman.Social Skills. Jurnal Psychology of Classroom Learning. Vol. 2. Detroit: Macmillan Reference USA, 2009. p843-847. 
Margus Pedaste. Phases of Inquiry-based learning: Definitions and the Inquiry cycle.Jurnal Online : Elsevier, Procedia - Educational Research Review Vol. 14 (2015) 47-61 ISSN 1747-938X (C) 2015 Published by Elsevier Ltd.

Markaban.2006. Model Pembelajaran Matematika dengan Pendekatan Penemuan Terbimbing. Yogyakarta: Pusat Pengembangan dan Penataran Guru Matematika.

Mince Tonda. Penerapan Model Pembelajaran Inquiry Untuk Meningkatkan Hasil Belajar IPS Siswa Kelas V SD.Jurnal Pendidikan Guru Sekolah Dasar Vol.1 Edisi 7,Tahun ke6-Mei 2017.

$\begin{array}{cr}\text { Mulyasa, E.(2012).Menjadi } & \text { Guru } \\ \text { Profesional. } & \text { Bandung: } \\ \text { Rosdakarya. } & \end{array}$

Nasution. (2005). Berbagai Pendekatan dalam Proses Belajar Mengajar.Jakarta: Bumi Aksara.

Ni Kadek Nanik Dwidayani. Meningkatkan Hasil Belajar Mata Pelajaran IPS Melalui Penerapan Model Inquiry Pada Siswa Kelas IV SD Inpres BajawaliKecamatan Lariang Kabupaten Maтuju Utara..Jurnal Kreatif Tadulako Online Vol. 3 No. 2ISSN 2354-614X

Putri Admi Perdani. Peningkatan Keterampilan Sosial Melalui Metode Bermain Permainan Tradisional Pada Anak TK B. Jurnal PENDIDIKAN Anak Usia Dini PPs UNJ. Volume 7 Edisi 2, November 2013,h. 337.

Rahmat. Games Book sebagai Media Peningkatan Minat Baca pada Pembelajaran Bahasa Indonesia SD Kelas Tinggi. Jurnal IJPE UPI, Vol 1 No 1 (2017) 27-33.

Ratni Sirait. Pengaruh Model Pembelajaran Inquiry Training terhadap Hasil Belajar Siswa pada materi pokok usaha dan energi panas. Jurnal Pendidikan Fisika UNIMED, Vol.1, No.1, Juni 2012, ISSN: 2252-732X.

Sanjaya,Wina. (2006).Strategi Pembelajaran Berorientasi Standart Proses Pendidikan.Jakarta : Kencana Prenada Media

Siti Masitoh. Peningkatan Hasil Belajar IPS melalui Strategi Inquiry Discovery Learning Di Kelas IV SDN Kecamatan Cikarang Utara Kabupaten Bekasi. Jurnal Pendidikan Dasar UNJ. Vol.7 Edisi 2 Desember 2016- p-ISSN 20867433 , e-ISNN 2549-5801.

Sharon A. Lynch and Cynthia G. Simpson. Social Skills: Laying the Foundation for Success. Journal Spring/Summer. Volume 38, Number 2, 2010 , h.3.

Singleton.(1983). Social Skill: The Study og Real Skill. England: MTP Press Limited

Stephen N. Elliott. (2016).Social Skill Development in Early Childhood Enabling Learning, Growing Friends.USA:Learning Sciences Institute Arizona State University.

Sumantri,M. 2015. Strategi Pembelajaran Teori dan Praktik di Tingkat Pendidikan Dasar. Jakarta: PT Raja Grafindo Persada.

Supardi.(2015).Penilaian Autentik Pembelajaran Afektif, Kognitif dan Psikomotor. Jakarta:Rajawali Pers.

Susanto, Ahmad.2013.Teori Belajar dan Pembelajaran di Sekolah Dasar. Jakarta: Kencana.

Yulia Siska. Penerapan Metode Bermain Peran dalam meningkatkan Keterampilan Sosial dan Keterampilan Berbicara Anak Usia Dini. Jurnal Pendidikan Dasar. Eds. Khusus No. 2 Agustus 2011- ISSN 1412-56. 